\title{
Fiscal decentralization and economic growth in Colombia: evidence from regional-level panel data
}

\author{
Ignacio Lozano and Juan Manuel Julio
}

ABSTRACT

This paper provides evidence for the positive effects of fiscal decentralization on regional economic growth in Colombia since the enactment of the Political Constitution of 1991. The empirical strategy involved choosing a suitable estimator for the panel data approach, the augmented mean group (AMG) estimator, that enabled unobserved determinants suggested by the literature to be added to traditional long-term explanatory factors. The strategy was supplemented with exercises that provided support for the results from (i) cross-sectional models for different periods and various control variables; (ii) a test of the hypothesis of complementarity between public goods provided by different jurisdictions (spillover effects), and (iii) an assessment of unconditional convergence in regional income differences. Colombia. ilozanes@banrep.gov.co

Juan Manuel Julio is a senior researcher with the Research Unit of the Bank of the Republic in Bogota, Colombia, and a part-time associate professor with the Department of Statistics at the National University of Colombia. jjulioro@banrep.gov.co 


\section{I}

\section{Introduction}

The decentralized provision of public goods has usually been seen as an important channel for encouraging regional economic development. The canonical theoretical assumption is that local governments are more efficient at allocating public resources, since they have better information and stronger incentives to get things right than the central government. Firstly, local authorities will eventually supply the goods that people prefer, as they are closer to the population (Oates, 1999). Secondly, subnational governments that provide basic services are under the scrutiny of their constituents and so have incentives to execute public policies in accordance with the interests of the community (Tiebout, 1956). Decentralization might also be beneficial for governance and market mechanisms, favouring private activities (Tulchin and Selee, 2004; Weingast, 1995). In practice, the combination of these factors may be conducive to learning, experimentation and competition in the provision of collective consumption goods, thus fostering long-term economic growth.

Nevertheless, the welfare gains from decentralized fiscal arrangements have been called into question by other branches of the literature. Scale economies, for instance, might mean that central governments are more efficient than local ones at producing public goods optimally, thanks to advantages in the organization and use of technologies (Stein, 1998). In addition, local governments could be less well able to plan and implement projects, mainly because their human resources are likely to be less educated or experienced (Iimi, 2005). From the perspective of political science, decentralized systems are likely to be more exposed to the risks of corruption and rent-seeking, with negative effects on economic activities (Rodden and Rose-Ackerman, 1997; Brueckner, 2001; Fisman and Gatti, 2002; Bardhan and Mookherjee, 2005).

Empirically, there are numerous studies analysing the effects of fiscal decentralization on economic growth,

$\square$ The authors would like to express their gratitude to Aura García, Laura Ardila and Lina Ramírez for their valuable assistance during the research. The opinions and conclusions expressed in this paper are the authors' own and may not reflect those of the Bank of the Republic, its Board of Governors or the National University of Colombia. both across countries and in single cases. The results are manifold and point in all sorts of directions. Surprisingly, early papers from the 1990s yielded little in the way of consensus about the benefits of fiscal decentralization for economic activity, but the findings have been changing recently (Blöchliger, 2013; Kim, 2013; Asatryan, 2010; Baskaran, Feld and Schnellenbach, 2009).

Fiscal decentralization was implemented in Colombia in the early 1990s, after 30 years of trying. By that time, most Latin American countries were strengthening the role of regional governments in economic development. Indeed, this type of reform was taking place worldwide. According to several studies, 63 of the 75 countries with a population over 5 million have undergone major decentralization since 1980 (Lee and Roy, 1999; Manor, 1999; Oxhorn, Tulchin and Selee, 2004). Thus, broadly speaking, decentralization became the core of institutional reforms during the late twentieth century, especially in developing countries.

The advance of decentralization in Colombia has touched many aspects of government. Where resourcing is concerned, the process has been based on a gradual increase of financial transfers from central to regional governments. However, progress in devolving powers and responsibilities has been less clear. On the political side, popular election of mayors started in 1988 and that of departmental governors in 1992. The free choice of regional governors and mayors became a key strategy of democratic reformers, who wanted to ensure that decentralization would make the State more accessible to citizens as well as counterbalance the abuse of power by national leaders. Finally, central government fund transfers were supplemented from 2000 by other measures, such as those designed to prevent financial disequilibria in regional entities while strengthening physical investment.

The Colombian literature includes papers analysing the effects of fiscal decentralization on the coverage of education and health services (Melo, 2005; Faguet and Sánchez, 2008 and 2009) and other public utilities (Sánchez, 2006). Non-linearity between decentralization and education coverage and its impact on quality have also been investigated (Lozano and Martínez, 2013). Other papers have addressed related issues such as: 
(i) the response by different municipalities to the system of intergovernmental transfers (Loboguerrero, 2008); (ii) the fairness of the transfer system (Bonet, 2006); (iii) the relationship between decentralization and armed conflict (Sánchez and Chacón, 2005; Villa, Restrepo and Moscoso, 2014), and (iv) the effect of decentralization on poverty at the municipal level (Ramírez, Díaz and Bedoya, 2014).

Two decades after the 1991 adoption of the Constitution, which paved the way for fiscal decentralization in Colombia, there is still no evidence to show whether it has strengthened regional economic growth or not. As described above, the most relevant empirical studies have focused on assessing its impact on certain production factors, but not directly on output. This is the gap we try to fill in this paper, which also provides evidence on the spillover effects of public goods provision by different jurisdictions and on regional growth convergence.

Following this Introduction, the paper is organized as follows. Section II provides an overview of some institutional aspects and major indicators of fiscal decentralization in Colombia. Section III briefly describes the economic model adopted to evaluate the subject. Section IV discusses the links between economic theory and the statistical model to be estimated, highlighting the main empirical issues. The results are presented and discussed in section $\mathrm{V}$, and the paper concludes in section VI with some final remarks.

\section{II}

\section{An overview of fiscal decentralization in Colombia}

Although the Political Constitution of 1991 propelled Colombia's decentralization process, important measures had actually begun three decades earlier, when the central government began transferring a significant percentage of its tax revenues to the regions (Act 33 of 1968 and Act 46 of 1971). During the 1980s, the replacement of the sales tax by value added tax (VAT) under Act 14 of 1983 introduced new changes into the system of transfers to municipalities. The main one was the gradual increase in VAT transfers to $50 \%$, a level that was to be reached in 1992 (Act 12 of 1986). The Constitution of 1991 introduced new criteria for setting the size of transfers to the subnational departments (the so-called situado fiscal) and the amount and purpose of transfers to municipalities. The constitutional mandates were regulated by Act 60 of 1993. However, central government budget constraints made it unfeasible to increase transfers to the regions after the early 2000s. Consequently, two additional reforms to the transfer system were implemented at the turn of the century.

The first one combined the two existing transfer systems, the situado fiscal and the participación municipal into a single basket called the General Participation System (SGP) (Legislative Act 1 and Act 715 of 2001). The radical change it introduced was to separate the size of transfers from the current revenues of the central government by setting real growth rates. The SGP assigned new weights to the three major funding destinations: basic education $(58.5 \%)$, health $(24.5 \%)$ and a general-purpose destination $(17.0 \%)$ that included basic sanitation programmes (drinking water, sewage and refuse collection). As for the geographical distribution criteria, there were no substantial changes from the previous regime, with population size continuing to be the main variable for resource allocation (i.e. population served and to be served by education and health services, urban or rural location, conditions of extreme poverty, etc.). The second reform took place in 2007 and was basically aimed at rectifying the temporary system for calculating transfer amounts set up in 2001. This reform introduced higher real growth rates for the SGP until 2016, and added new resources for the education sector.

In the transition towards decentralization, financial transfers became the main source of revenue for many regional governments, both municipal and departmental. Such transfers have been particularly salient in regional government funding in Colombia, coming to represent nearly $50 \%$ of the total by the end of the 1990s. Of course, the extent to which dependence on them has increased varies from one municipality to another. The largest 
municipalities (those in the special and first categories, defined as having over 500,001 inhabitants and between 100,001 and 500,000 inhabitants, respectively, together with an income criterion) are far better able to finance their spending from locally raised taxes. By contrast, municipalities of the sixth category (the smallest) were only financing $13 \%$ of their spending from self-generated taxes in the late 1990s (Lozano and Martínez, 2013).

From an overall tax collection perspective, subnational governments in Colombia currently collect only a little less than $14 \%$ of tax revenues, while their share of total public expenditure is close to $44 \%$. Calculated by the most widely used indices, spending has clearly decentralized more quickly than revenue-raising, as shown by figure 1 for the region level. ${ }^{1}$ The degree of decentralization varies widely between regions, with

\footnotetext{
1 The indices are defined as subnational governments' share of general government expenditures and revenues (Blöchliger, 2013). More detail on these indicators is provided in section $\mathrm{V}$.
}

Bogota, Antioquia, Valle and Cundinamarca leading on both the expenditure and revenue indexes.

Figure 2 displays the sources of regional tax revenues and the distribution of spending on leading programmes financed out of both self-generated revenues and central government transfers. Locally raised tax revenues have increased from about $2 \%$ to $2.8 \%$ of gross domestic product (GDP) over the last 20 years, led by taxes on economic activity (those levied on commercial and industrial activities and consumption taxes on alcohol and cigarettes) and real estate. Overall spending increased by almost 5 percentage points of GDP (from $4.8 \%$ to $9.4 \%$ ), with the most significant rises being in the areas of education and health care (human capital) and infrastructure (physical capital). However, most of this growth took place over the course of the 1990s, probably as a result of the ambitious social commitments of the 1991 Constitution. Indeed, transfers from central government to the regions increased from about $2 \%$ to $4.6 \%$ of GDP between 1990 and 2003, stabilizing at around 4\% thereafter.

FIGURE 1

Fiscal decentralization, 1990-2012

(Revenue versus expenditure, index averages)

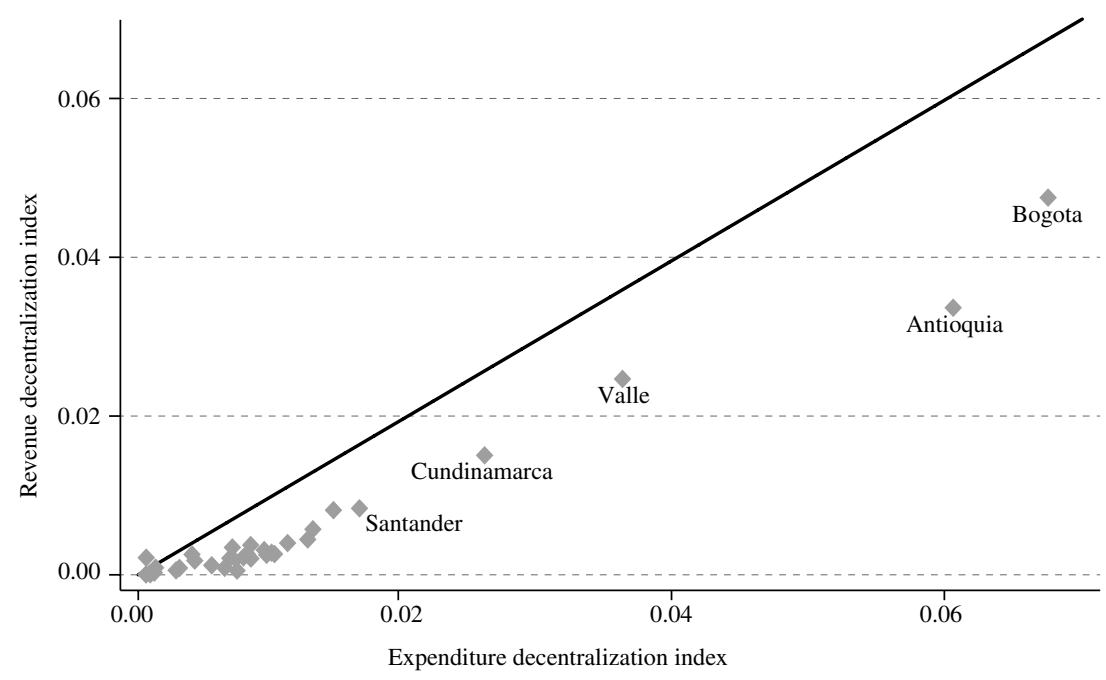

Source: Prepared by the authors. 


\section{Subnational government tax revenue and expenditure}

(Percentages of GDP)

Tax revenue

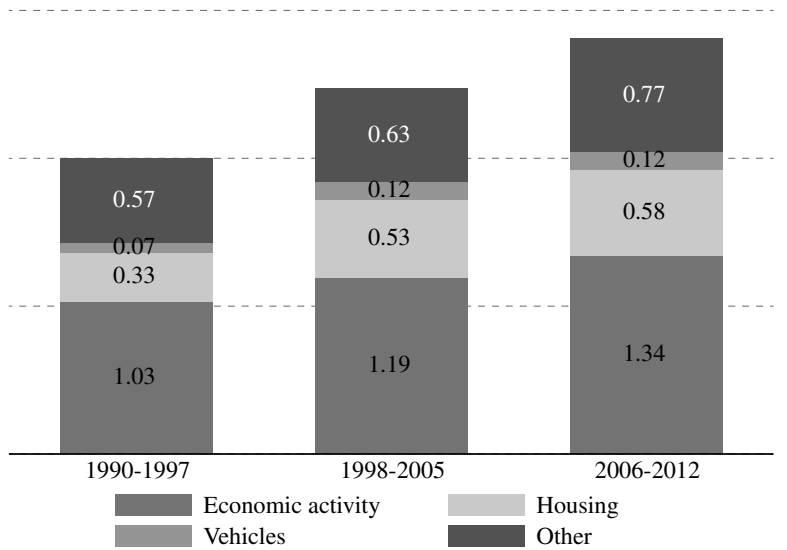

Expenditure

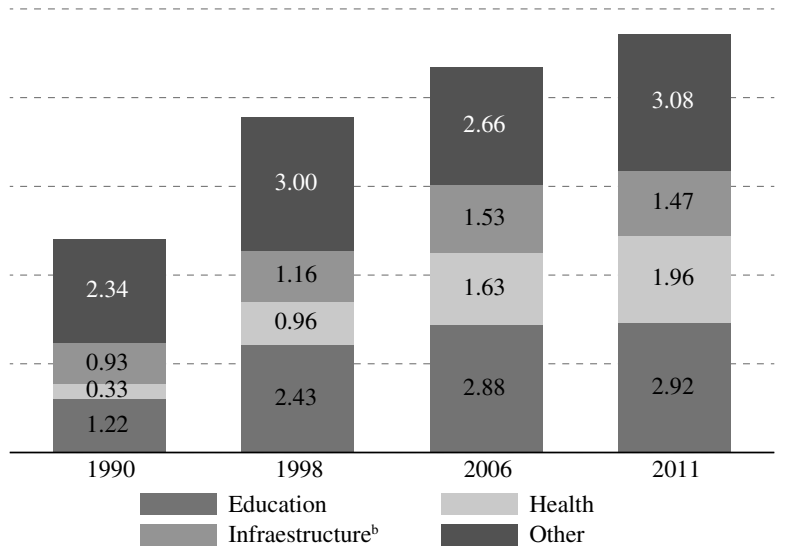

Source: Prepared by the authors.

Note: GDP: Gross domestic product.

a Expenditure financed from both local revenues and central government transfers.

b Owing to data limitations, the ratio of infrastructure spending to GDP for 2011-2012 was estimated by the authors.

Increasing subnational expenditure on infrastructure, human capital and other public services could have positive effects on regional economic growth, as may be inferred from figure 3. In the short term, higher spending could stimulate aggregate demand and hence economic activity, while over a longer time horizon it could positively affect factor accumulation and productivity. The correlation coefficient between the expenditure decentralization index and per capita GDP is positive across all regions, and while not particularly high (0.186) is statistically significant at a $99 \%$ confidence level. Once again, Bogota, Antioquia and Valle have the highest decentralization levels, while Arauca and Casanare, the oil-producing regions, have the highest levels of per capita GDP.

FIGURE 3

Simple correlation between decentralization and regional GDP, 1990-2012

(Index averages and millions of pesos)

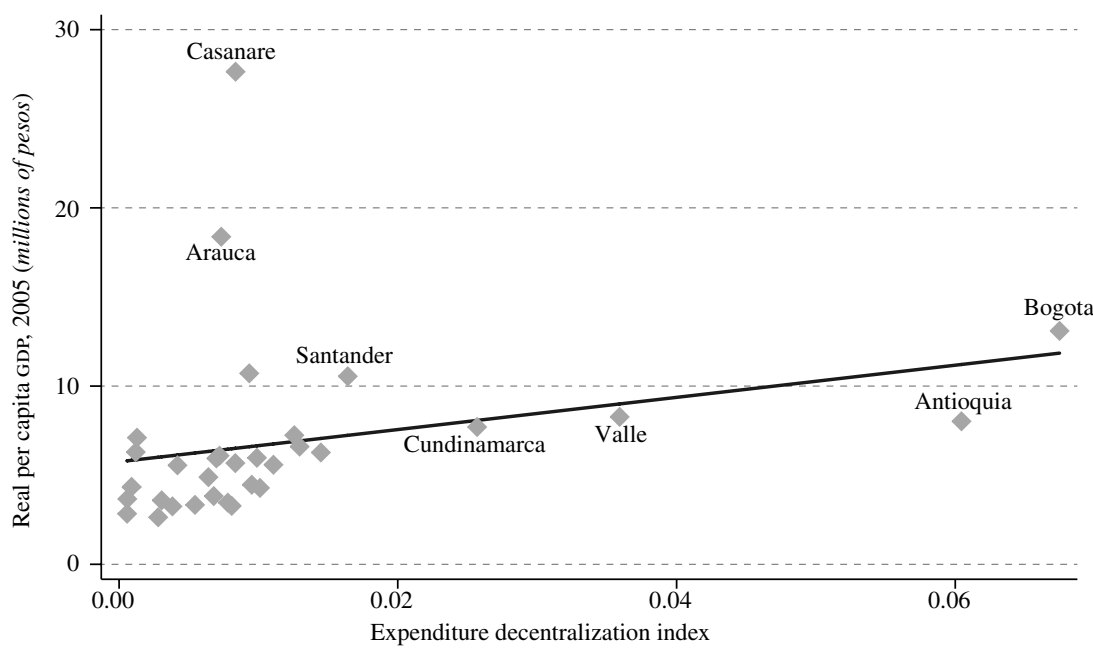

Source: Prepared by the authors.

Note: GDP: Gross domestic product. 


\section{III}

\section{The analytical framework}

\section{The basic configuration}

We start from a simple version of Barro's (1990) endogenous growth model, which assumes that the government purchases a portion of private-sector output to provide free public services to private producers (infrastructure services, property rights, etc.). Let $y$ be the output, $k$ the private capital and $g$ the government purchases, with all variables defined in per capita terms. Under constant returns to scale, the aggregate production function could be written as: $y=A k^{\alpha} g^{\varphi}$, where $0<\alpha<1$, $0<\varphi<1, \alpha+\varphi=1$ and $\mathrm{A}>0$ denotes the technology parameter. We omit the time subscripts for simplicity.

In order to introduce the fiscal decentralization discussion, government purchases are disaggregated into the shares financed by central, state and local authorities (Davoodi and Zou, 1998). Without loss of generality, we consider only two levels, namely central and local governments (Kim, 2013; Iimi, 2005), causing the production function to be written as follows:

$$
y=A k^{\alpha} f^{\beta} l^{\gamma}
$$

where $f$ denotes per capita central government purchases and $l$ those made by local government, $0<\beta<1$, $0<\gamma<1$ and $\beta+\gamma=\varphi$. Therefore, the degree of fiscal decentralization can be defined as local government spending relative to total public spending. As a result, the degree of fiscal decentralization increases if local government spending rises relative to that of central government, and vice versa. Accordingly, the allocation of total government spending $(g)$ between the different levels of government takes the following form:

$$
f=\theta_{f} g ; l=\theta_{l} g ; \theta_{f}+\theta_{l}=1
$$

where $0<\theta_{i}<1$ for $i=f$, $l$, with $\theta_{f}$ and $\theta_{l}$ being the shares of central and local government spending, respectively. On the revenue side, governments set a flat income tax rate $(\tau)$, keeping to the balanced budget constraint $(g=\tau y)$. The model is closed with standard preferences for a Ramsey-Cass-Koopmans (see Ramsey, 1928; Cass, 1965 and Koopmans, 1965) representative household, where $c$ is per capita private consumption and $\rho>0$ is the time discount rate. As usual, the dynamic budget constraint of the representative agent is given by $\frac{d k}{d t}=\dot{k}=(1-\tau) y-c=(1-\tau) k^{\alpha} f^{\beta} l^{\gamma}-\epsilon$. For a given level of $g$ and $\theta_{i}$, the steady-state solution for per capita output growth is given by:

$$
\frac{d y / d t}{y}=\frac{\dot{y}}{y}=\frac{1}{\sigma}\left[(1-\tau) \tau^{\frac{1-\alpha}{\alpha}} A \alpha\left(1-\theta_{l}\right)^{\frac{\beta}{\alpha}} \theta_{l}^{\frac{\gamma}{\alpha}}-\rho\right]
$$

The empirical long-term relationship between fiscal decentralization and economic growth may be assessed from the previous equation. In point of fact, increasing decentralization has a positive effect on growth as long as the productivity of local government spending is greater than that of the central government's, i.e. $\frac{d y / d y}{d \theta_{l}}>0$ for $\theta_{l}<\frac{\gamma}{\beta+\gamma}$. Additionally, for a given level of total government spending (as a share of GDP), a reallocation of public spending between different levels of government can lead to higher economic growth if the current allocation differs from the one resulting from a growth-maximizing expenditure problem, given by

$\theta_{f}^{*}=\frac{\beta}{\beta+\gamma}$ and $\theta_{l}^{*}=\frac{\gamma}{\beta+\gamma}$.

\section{Complementarity between public goods and unobservable determinants of growth}

Barro's growth model was extended by Nishimura (2006) and Akai, Nishimura and Sakata (2007) to capture complementarity between public goods provided by the regions within a country. Programmes implemented in each jurisdiction could have a spillover effect on others, and thence on the national economy. Thus, the discussion about the role of government in growth is not only about the benefits of a centralized versus a decentralized fiscal regime, but also about the spillover impacts of public goods financed across regions.

The complementarity hypothesis is incorporated through an aggregate production function for public goods, which depends partially on a large set of public inputs financed by subnational governments (education and health programmes, infrastructure, libraries, parks, property rights, social services, etc.). In practice, it 
implies letting $g=\sum_{i=1}^{I} l_{i}+f$ in Barro's model, where $i=1, \ldots, I$ is the number of regional units.

The extended framework, called the human fallibility model of government, assumes that there are $J$ identical jurisdictions in each region $i$, each of them with the same number of firms and households. Some public programmes might generate positive spillover effects on growth (externalities) at both the interregional and intraregional levels while others do not. If $p(j)$ denotes the public programmes financed by jurisdiction $j$, then the aggregate public good in a region $i\left(l_{i}\right)$ is a function of the public services provided by $J$.

$$
l_{i}=\left(\sum_{j=1}^{J} \frac{1}{J} p(j)^{\rho}\right)^{\frac{1}{\rho}}, \quad \rho \geq 0
$$

Equation (4) represents the public goods production function for region $i$, which depends on inputs (programmes) provided by the jurisdictions $J$ (municipalities). Furthermore, $\rho$ captures the degree of global (inter-)complementarity between public services, to use the terminology of Bénabou (1996). A higher value of $\rho$ means lower complementarity and vice versa. Empirically, it is usual to treat expenditure on the public programmes financed by jurisdiction $j$ as a proxy for their effectiveness. Section IV will add other technical details of the method used to estimate $\rho$.

Aside from the usual factors determining long-term economic growth and the role of regional governments, an important branch of the literature has focused on models in which spatial considerations are crucial (Breinlich, Ottaviano and Temple, 2013). This approach points out that economic activities tend to gravitate mainly towards areas that have relatively good transport links and are close to large markets. Therefore, regional growth performance could be connected with geographical features in addition to other unobservable determinants (culture, the quality of institutions, etc.). If outcomes in one region are closely linked to the outcomes and characteristics of other regions (i.e. there is spatial interdependence), the econometric strategy has to reflect this. Our empirical exercises also pay particular attention to these issues. The technical details will be discussed further in the next section.

\section{IV}

\section{Linking the economic theory to a statistical model}

We begin by using the equation:

$$
y_{i t}=\beta_{i}^{\prime} x_{i t}+u_{i t}
$$

where $x_{i t}=\left[\begin{array}{ll}d_{i t} & k_{i t}\end{array}\right]^{T}, d_{i t}$ is a fiscal decentralization indicator for region $i=1,2, \ldots, N$ and period $t=1,2, \ldots$, $N, \beta_{i}$ is a vector of region-specific slopes (technology) and $u_{i t}$ is closely related to (unobservable) total factor productivity (TFP) growth, $\triangle T F P$, for regions and periods.

The following assumptions in equations (6) to (8) yield a (possibly non-stationary) dynamic factor system representation of the observable and unobservable variables in $N$ correlated regions:

$$
\begin{gathered}
u_{i t}=\alpha_{i}+\lambda_{i}^{\prime} f_{t}+\varepsilon_{i t} \\
x_{m i t}=\pi_{m i}+\delta_{m i}^{\prime} g_{m t}+\rho_{1 m i} f_{1 m t}+\cdots+\rho_{n m i} f_{n m t}+v_{m i t} \\
f_{m t} \subset f_{t} ; f_{t}=\searrow^{\prime} f_{t-1}+\epsilon_{1 t} ; g_{t}=\chi^{\prime} g_{t-1}+\epsilon_{2 t} ; \epsilon_{t}=\left[\epsilon_{1 t}^{\prime} \epsilon_{2 t}^{\prime}\right]^{\prime}
\end{gathered}
$$

Under assumption (6), the unobserved $\triangle T F P$ splits into a common (cross-regional) unobserved time-varying total factor productivity component $\left(f_{t}\right)$, a fixed regional factor productivity effect $\left(\alpha_{i}\right)$ and a time- and sectorvarying TFP innovation $\left(\varepsilon_{i t}\right)$. Assumption (7) implies, in turn, that each observable factor of $x_{i t}, x_{m i t} \subset x_{i t}$, for $m=1,2$ (i.e. $x_{1 i t}=d_{i t}$ and $x_{2 i t}=k_{i t}$ ), depends on: (i) a set of unobserved time-varying but variable-specific factors that are common across regions, $g_{m t}$; (ii) a subset of the factors $f_{n m t} \subset f_{t}$ driving TFP; (iii) a set of effects that are variable-dependent but fixed across regions $\left(\pi_{m i}\right)$, and (iv) an innovation $v_{\text {mit }}$ that changes with the time, the region and the variable explained in (7). Finally, with equation (8), the common factors driving TFP, fiscal decentralization and private capital growth, follow $\operatorname{VAR}(1)$ dynamics.

According to Banerjee, Eberhardt and Reade (2010), the statistical model in equations (5) to (8) represents a production-related function with (i) observed 
heterogeneous technology across regions; (ii) possibly integrated observable and unobservable variables; (iii) spillovers and spatial cross-correlations between the observable and unobservable variables across regions; (iv) observed and unobserved heterogeneity among variables; (v) endogenous factors of production, and (vi) observable as well as unobservable dynamics. On this last, see Bond and Eberhardt (2013), Baltagi, Bresson and Pirotte (2008) and Hsiao and Pesaran (2008).

The last two equations bring out three broad sources of variation in fiscal decentralization. The first source are time-varying shocks that affect fiscal decentralization equally across regions $\left(g_{1 t}\right)$, such as central government transfer policies. This source is, therefore, the first element of $\varepsilon_{2 t}$. The second source are region-specific time-varying shocks $\left(v_{1 i t}\right)$, which may arise, for example, from idiosyncratic tax or spending policies. The third source are factor productivity shocks common to all regions $\left(f_{n 1 t}\right)$, such as countrywide policies on tax-raising or spending, that can induce correlations between regional output growth and fiscal decentralization through spillovers between regions. This third source of shocks is one element of $\varepsilon_{1 t}$.

As a result, a one-time innovation in fiscal decentralization has a transitory effect on output growth and a permanent effect on per capita output. Indeed, all else being equal, a one-time positive shock to the first

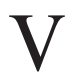

\section{Results}

\section{The dataset}

Our dataset contains yearly records of the variables described in annex I for 24 Colombian regions spanning the 1990-2012 period. Unfortunately, complete information is not available for all 32 regions in the country, but the 24 regions in our sample account for an average of $97.7 \%$ of national GDP. The variables employed in the panel data regressions are described in annex A1, as are other variables used in the cross-sectional exercises and those required to assess the complementarity effect among public goods.

Two particular remarks must be made about the dataset. The first concerns the fiscal decentralization element of $\varepsilon_{2 t}$, i.e. a fiscal decentralization innovation, or one element of $\varepsilon_{1 t}$, i.e. a common TFP innovation affecting fiscal decentralization, transmits through an $\operatorname{AR}(1)$ process to $g_{t}$ or $f_{t}$, respectively, and thence, through the same $\operatorname{AR}(1)$ process, to regional per capita output growth. When this response is integrated, therefore, a permanent shift in regional per capita output arises. Furthermore, a one-time positive time-varying regionidiosyncratic fiscal decentralization shock $v_{1 i t}$ translates, other things being equal, into one-time regional per capita output growth of size $\beta_{1}$, which after integration becomes a permanent shift in the output level of the same size. Therefore, regardless of whether fiscal decentralization shocks are common or idiosyncratic in origin, per capita output shifts permanently upward in the long term.

Estimation is carried out using the augmented mean group (AMG) technique proposed by Eberhardt and Teal (2010) and Bond and Eberhardt (2013). Just like the earlier choice of statistical model, this choice was dictated by the very moderate size of the dataset available. Under these circumstances, several of the parameters that are not of interest are treated as a nuisance. In fact, under the assumption that regional technology vectors $\beta_{i}$ are random with mean $\bar{\beta}$, only the latter is identified and can consistently be estimated. See Coakley, Fuertes and Smith (2006). indicators based on expenditure and revenues $\left(d_{i t}\right)$. Autonomous expenditure and taxes were taken as the most relevant measures in our framework. Autonomous expenditure is spending by the government of region $i$ excluding transfers from the central government (i.e. expenditure financed out of the region's own resources). Autonomous taxes are those over which subnational governments have some degree of legal autonomy delegated by central government. These measures were supplemented by a measure of subnational government expenditure as a share of total general government expenditure, this ratio being one of the most commonly employed indicators for studies at panel data level across countries (Blöchliger, 2013). The higher the ratio, the greater the 
level of decentralization in that region. ${ }^{2}$ Autonomous revenue as a share of the total was likewise included.

The second remark concerns estimation of the stock of private capital at regional level $\left(k_{i t}\right)$, as this information is unfortunately unavailable in Colombia. Use was originally made of the initial value of the aggregate capital stock as calculated by the National Planning Department (DNP) with the permanent inventories methodology. This value was updated using net investment as reported in the national accounts and a standard yearly depreciation rate of $4.92 \%$. The next step was to identify the public component of capital over the time period (and thence the private component), the weight used being infrastructure spending (a proxy for public investment) as a percentage of total investment, again as reported in the national accounts. In the final step, two complementary tools were used to proxy the regional distribution of private capital. First, the figures were weighted by the distribution of output between regions, on the standard assumption that capital and output grow at equal rates in the steady state. Second, the regional distribution of manufacturing firms' capital, identified from the Annual Manufacturing Survey, was factored into the calculations.

\section{Growth regression models}

Prior to the findings being presented, some statistical properties of the variables involved in the panel data models were examined (unit root, stationarity and crosssectional dependence). Annex A2 shows the results. First, the standard unit root tests reject the presence of unit roots in the variables included in equation (5) (for different versions), which means that these versions of the equation are stationary panels. Second, Pesaran's (2004) cross-sectional dependence (CD) test strongly suggests the existence of variable-wise cross-sectional dependence among the 24 regions in Colombia considered. Third, principal components analysis suggests that unobservable dynamic factors might have to be brought in to explain the total variation of regional economic growth in Colombia, something that is in fact done by the AMG estimator used in this paper.

\footnotetext{
${ }^{2}$ Public spending in region $i$ encompasses both operational and investment spending by the departmental government of $i$ plus expenditures by all municipalities belonging to this region. One important source of financing for regional expenditures consists of transfers from central government, especially for education. For a typical region $i$, education expenditures financed from transfers averaged $32 \%$ of total spending between 2002 and 2012. The remaining expenditure (more than two thirds) was in other areas such as infrastructure, health, debt service, administration, etc.
}

Table 1 shows the results of the model described by equations (5) to (8), based on the AMG estimator, which was designed for moderate panel size and was used in the presence of heterogeneous slope coefficients across regions and possible correlation across the panel members. The signs of the parameters are as theoretically expected, and the model seems to explain growth mechanisms aptly. The key coefficients of fiscal decentralization are positive and statistically significant, implying that the transfer of fiscal functions to subnational governments may have strengthened economic growth. Expenditure autonomy indicators, for instance (model 1), indicate that a $10 \%$ increase in spending autonomy in a representative region $i$ could lead in the long term to an increase of $2.4 \%$ in economic growth.

The higher coefficient of the tax autonomy indicator (model 2) is surprising because there is currently limited scope for subnational governments to manage their own taxes. This may be a potential source of growth to be examined, as it is reasonable to argue that fiscal spending decentralization has also been associated with a strengthening of regional income bases. Finally, fiscal decentralization as measured by spending and revenue shares has been positive and statistically significant, although with semi-elasticity greater than 1 .

The positive effect of fiscal decentralization on regional economic growth is explained by channels associated with demand as well as supply. Taking the indicator of fiscal decentralization based on expenditure (model 3), for instance, the relative growth of subnational expenditure on infrastructure, human capital and other public services could have positive effects on regional economic growth both in the short term, through the stimulus to aggregate demand (contemporary effect), and on a longer time horizon, owing to the positive effects on factor accumulation and productivity (TFP). It should be recalled that this parameter measures the average effect across both agents and time.

The positive links found between fiscal decentralization and regional economic growth in Colombia are consistent with most recent papers on the subject. Nonetheless, some have argued that this relationship is positive but non-linear, suggesting a hump-shaped association (Akai, Nishimura and Sakata, 2007; Blöchliger, 2013). The "optimal" level of decentralization yielded by this discussion thus fixes a limit beyond which additional decentralization may restrain rather than encourage economic activity. We explored this hypothesis using the Colombian data, but no evidence for it was found, perhaps because the series are not long enough. 
TABLE 1

Panel data results

\begin{tabular}{|c|c|c|c|c|}
\hline \multirow{2}{*}{$\begin{array}{l}\text { Variable } \\
\text { Fiscal decentralization }\end{array}$} & \multicolumn{2}{|c|}{ Fiscal autonomy } & \multicolumn{2}{|c|}{ Fiscal share } \\
\hline & (1) & (2) & (3) & (4) \\
\hline Expenditure autonomy, $d_{i t}$ & $0.0246 * * *$ & & & \\
\hline Tax autonomy, $d_{i t}$ & & $0.1302 * * *$ & & \\
\hline Expenditure share, $d_{i t}$ & & & $1.5404 * * *$ & \\
\hline Revenue share, $d_{i t}$ & & & & $1.5100^{*}$ \\
\hline Per capita private capital, $k_{i t}$ & $0.6159 * * *$ & $0.5946 * * *$ & $0.6026 * * *$ & $0.6110 * * *$ \\
\hline Common factors effect, $\lambda_{i t}$ & $0.8323 * * *$ & $0.8084 * * *$ & $0.7672 * * *$ & $0.8461 * * *$ \\
\hline Constant (regional fixed effect), $\propto_{i t}$ & $-0.0158 * * *$ & $-0.0507 * * *$ & $-0.0325 * * *$ & $-0.0231 * *$ \\
\hline
\end{tabular}

Number of observations $=528$

Number of groups $=24$

Source: Prepared by the authors.

Note: The dependent variable is the average annual per capita GDP growth rate. The common dynamic process is included as an additional regressor. $* * * p<0.01 ; * * p<0.05 ; * p<0.1$.

Regarding the other results, the expected sign of the private capital parameter is confirmed with the highest statistical significance across the models and a reasonable degree of elasticity. However, what is more striking is the positive result for the common unobservable factors that help to explain the economic growth of regions directly, as well as factor accumulation and productivity. In the theoretical setting of Eberhardt and Bond (2009), the TFP of the production function is paramount among the unobservable factors. Nevertheless, some particular differential aspects recognized by the literature as crucial determinants of development across countries (regions), such as culture, habits, climate, geographical aspects, the quality of institutions, etc. (Acemoglu, Johnson and Robinson, 2005), could also be included as unobservable factors. Due to the unavailability of data for these estimations, we were unfortunately unable to distinguish between parameters.

To check the validity of the foregoing results, residual unit root tests and cross-sectional dependence tests were performed for the residuals of each panel estimated. The results in table 2 confirm the rejection of residual unit roots since the $p$-values of the Levin, Lin and Chu (2002) unit root tests are well below 0.05 . Moreover, table 2 also shows strong evidence of a lack of residual cross-dependence, since the $p$-values of the Pesaran's (2004) cross-dependence tests range from 0.45 to 0.82 . As a result, table 2 suggests that our residuals successfully support the assumptions.
Furthermore, a principal components analysis of the residuals of each panel estimated reveals that commonality is greatly reduced. The results in table 3 show a large reduction in the correlation share of the first residual principal component with respect to the common correlation of GDP growth (see annex A2). A large portion of commonality was thus captured by the model, validating our empirical strategy.

TABLE 2

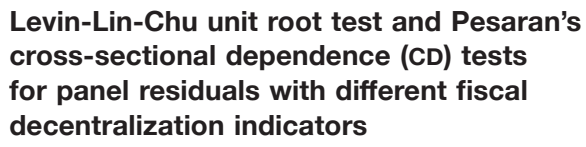

\begin{tabular}{|c|c|c|c|c|}
\hline \multirow{2}{*}{$\begin{array}{l}\text { Panel residuals } \\
\text { with each fiscal } \\
\text { decentralization } \\
\text { indicator }\end{array}$} & \multicolumn{2}{|c|}{ Levin-Lin-Chu test ${ }^{\mathrm{a}}$} & \multicolumn{2}{|c|}{ Pesaran CD test ${ }^{\mathrm{b}}$} \\
\hline & Coefficient & $p$-value & Coefficient & $p$-value \\
\hline $\begin{array}{l}\text { Expenditure } \\
\text { autonomy, } d_{i t}\end{array}$ & -1.14 & 0.00 & -0.23 & 0.82 \\
\hline Tax autonomy, $d_{i t}$ & -1.09 & 0.00 & 0.76 & 0.45 \\
\hline $\begin{array}{l}\text { Expenditure } \\
\text { share, } d_{i t}\end{array}$ & -1.15 & 0.00 & -0.30 & 0.76 \\
\hline Revenue share, $d_{i t}$ & -1.13 & 0.00 & -0.29 & 0.77 \\
\hline
\end{tabular}

Source: Prepared by the authors.

a Under the null hypothesis of non-stationarity.

b Under the null hypothesis of cross-sectional independence, $\mathrm{CD} \sim \mathrm{N}(0.1)$. 
TABLE 3

Principal components analysis of the residuals with different indicators of fiscal decentralization

\begin{tabular}{|c|c|c|c|c|c|c|c|c|}
\hline \multirow{3}{*}{ Order } & \multicolumn{4}{|c|}{ Fiscal autonomy } & \multicolumn{4}{|c|}{ Fiscal share } \\
\hline & \multicolumn{2}{|c|}{ Expenditure, $d_{i t}$} & \multicolumn{2}{|c|}{ Taxes, $d_{i t}$} & \multicolumn{2}{|c|}{ Expenditure, $d_{i t}$} & \multicolumn{2}{|c|}{ Revenue, $d_{i t}$} \\
\hline & (1) & $(2)$ & (1) & (2) & (1) & $(2)$ & (1) & $(2)$ \\
\hline 1 & 0.20 & 0.20 & 0.19 & 0.19 & 0.19 & 0.19 & 0.21 & 0.21 \\
\hline 2 & 0.13 & 0.33 & 0.12 & 0.31 & 0.13 & 0.32 & 0.13 & 0.33 \\
\hline 3 & 0.12 & 0.45 & 0.12 & 0.43 & 0.12 & 0.44 & 0.12 & 0.46 \\
\hline 4 & 0.10 & 0.55 & 0.11 & 0.54 & 0.09 & 0.54 & 0.10 & 0.56 \\
\hline 5 & 0.09 & 0.64 & 0.09 & 0.63 & 0.08 & 0.62 & 0.08 & 0.64 \\
\hline 6 & 0.07 & 0.71 & 0.07 & 0.69 & 0.08 & 0.70 & 0.08 & 0.72 \\
\hline 7 & 0.06 & 0.77 & 0.05 & 0.75 & 0.06 & 0.76 & 0.05 & 0.77 \\
\hline 8 & 0.05 & 0.82 & 0.05 & 0.80 & 0.05 & 0.81 & 0.05 & 0.82 \\
\hline
\end{tabular}

Source: Prepared by the authors.

Note: (1) is the proportion of explained variance and (2) is the explained variance.

Table 4 shows the results of the growth regression model, this time in a cross-sectional dimension as an alternative configuration to enable other types of controls to be introduced. Each column represents the model estimated for each fiscal decentralization indicator in different periods. The aim here is to verify the effects of fiscal decentralization on regional economic growth by controlling for the initial levels of output and human capital, measured from the starting level of education coverage. As can be seen, the sign of the fiscal decentralization and private capital parameters continues to have the highest level of statistical significance. Interestingly, the impact of fiscal decentralization on economic growth, as assessed from the expenditure and tax autonomy indicators, has grown in recent times. Also notable is the negative and significant parameter found for the starting level of GDP, suggesting convergence in regional economic growth in Colombia. This subject will be returned to later with formal tests. In addition, an unexpected sign was found for the initial human capital parameter. This is not exclusive to our paper and requires more detailed analysis (see Davoodi and Zou, 1998).

TABLE 4

Cross-sectional results

\begin{tabular}{|c|c|c|c|c|}
\hline \multirow{2}{*}{ Variable } & $\begin{array}{l}\text { Expenditure } \\
\text { autonomy }\end{array}$ & $\begin{array}{c}\text { Tax } \\
\text { autonomy }\end{array}$ & $\begin{array}{l}\text { Expenditure } \\
\text { share }\end{array}$ & $\begin{array}{l}\text { Revenue } \\
\text { share }\end{array}$ \\
\hline & $2000-2012$ & $2000-2012$ & $1990-2012$ & $1990-2012$ \\
\hline Fiscal decentralization indicator, $d_{i}$ & $0.0906^{* * *}$ & $0.0312 * * *$ & $0.1588 * * *$ & $0.1324 * * *$ \\
\hline Private capital, $k_{i}$ & $1.0679 * * *$ & $0.7697 * * *$ & $0.4127 * * *$ & $0.6260 * * *$ \\
\hline Initial per capita GDP level & $-8.92 \mathrm{e}-09 * *$ & $-9.83 \mathrm{e}-09 * *$ & $-1.10 \mathrm{e}-08 * * *$ & $-1.12 \mathrm{e}-08 * * *$ \\
\hline Initial education coverage level & $-0.0787 * * *$ & $-0.0382 * * *$ & $-0.0181 * * *$ & $-0.0307 * * *$ \\
\hline Constant & -0.0018 & $0.0308 * * *$ & $0.0354 * * *$ & $0.0412 * * *$ \\
\hline Number of observations & 24 & 23 & 22 & 22 \\
\hline
\end{tabular}

Source: Prepared by the authors.

Note: The dependent variable is the average annual per capita GDP growth rate. $* * * p<0.01 ; * * p<0.05$. 


\section{Complementarity between public goods}

To empirically assess complementarity between public goods provided by subnational governments (section III.2), we follow the strategy proposed by Akai, Nishimura and Sakata (2007), which starts by linearizing the production function of section III.1.

$$
\ln Y_{i, t}=B+(1-\beta) \ln K_{i, t}+\beta\left(\ln l_{i, t}+\ln N_{i, t}\right)
$$

where $\ln Y_{i, t}$ is the logarithm of the per capita GDP of region $i, \ln K_{i, t}$ is the logarithm of per capita private capital, and $\ln N_{i, t}$ is the number of workers per capita in each region, calculated as the ratio of the economically active population to the total population. In turn, the value of $\ln l_{i, t}$ is the logarithmic form of equation (4), where $p(j)$ denotes the implementation of public programmes financed by jurisdiction $j$. That is:

$$
\begin{gathered}
\ln l_{i, t}=\frac{1}{\rho} \ln \left\{\frac{1}{J} \sum_{j=1}^{J} p_{t}(j)^{\rho}\right\} \quad \text { (10) } \begin{array}{l}
\text { from the following second-order non- } \\
\text { using pooled non-linear least squares: }
\end{array} \\
\hat{\theta}=\underset{\theta \in R^{2}}{\operatorname{argmin}}\left\{\sum_{t=1}^{T} \sum_{i=1}^{N}\left(\ln Y_{i, t}-\left[B+(1-\beta) \ln K_{i, t}+\beta\left(\ln l_{i, t}+\ln N_{i t}\right)\right]\right)^{2}\right\}
\end{gathered}
$$

For the case of Colombia, we construct $\ln l_{i, t}$ by defining $p_{t}(j)=m_{j}+d_{j}$, where $m_{j}$ is spending by municipality $j$ and $d_{j}$ is the municipality's share (aliquot) of total expenditure in the department to which it belongs. The size of the population ( $p o p$ ) of each municipality relative to its department is used to weight this aliquot, so that $d_{j}=\frac{\operatorname{pop}_{j}}{\operatorname{pop}_{i}} l_{i}$. As suggested by the literature, the public expenditure relevant to this calculation includes in particular that associated with capital formation (investment), which has greater potential to generate spillovers. Thus, infrastructure expenditure in region $i$ on roads, electricity, parks, mass transit systems and so on could have beneficial effects on neighbouring regions because of considerations of spatial or geographical dependence, and vice versa. The parameters are estimated from the following second-order non-linear equation where $\theta=[\beta, \rho]^{T}$ is the parameter vector. The estimation was carried out by unrestricted numerical minimization of the right-hand term of equation (11) using the SAS/IML software. The data cover the 13 most representative regions of the Colombian labour market for the 20012012 period. ${ }^{3}$ The results are summarized in table 5 and compared with previous estimations by Akai, Nishimura and Sakata (2007) for the United States.

The null hypothesis of $\rho=0$ is rejected with a $1 \%$ significance level, so that the resulting value of $\rho$ is

3 The labour market data were taken from Colombia's National Administrative Department of Statistics (DANE). They report information only for the most representative 13 regions. Because of changes in survey methodology, information is available only from 2001 to 2012 . significantly positive for Colombia. According to the theory, this is the case when public goods provided at subnational levels are complementary among themselves or have spillover effects across regions, ultimately strengthening economic growth at the national level. From comparison with the United States we conclude that regional public goods in Colombia have a relatively small complementary effect, since the larger parameter $\rho$ is, the smaller its effect (section III.2). The private capital parameter $(1-\beta)$ is highly significant and close to what was obtained through the panel data regressions. For its part, the value of $B$ must be taken with caution, since this is not a dynamic growth analysis, which means that the implications for the Solow residual are not

\begin{tabular}{|c|c|c|c|c|c|c|}
\hline \multirow{2}{*}{ Parameter } & \multicolumn{3}{|c|}{ Colombia: 13 regions, 2001-2012 } & \multicolumn{3}{|c|}{ United States: 50 states, 1992-1997 } \\
\hline & Estimate & $t$-statistic & $p$-value & Estimate & $t$-statistic & $p$-value \\
\hline$B$ & 3.38 & 11.63 & 0.000 & 3.35 & 3.67 & 0.000 \\
\hline$\beta$ & 0.47 & 5.19 & 0.000 & 0.34 & 5.35 & 0.000 \\
\hline$\rho$ & 0.78 & 3.26 & 0.000 & 0.48 & 3.98 & 0.000 \\
\hline
\end{tabular}
entirely clear.

TABLE 5

Estimation of the public goods complementarity effect

Source: Authors' calculations for Colombia and Akai, Nishimura and Sakata (2007) for the United States.

Note: The dependent variable is the log of per capita GDP in the 13 most representative regions. 


\section{Regional growth convergence}

An important feature of this dataset is the large gap in per capita GDP levels between regions in Colombia. In 2010, for instance, per capita GDP was almost seven times as high in the richest regions (Casanare and Meta) than in the poorest (Sucre, Nariño and Chocó), the national average being about Col\$ 7.8 million (see Lozano and Martínez, 2013). The natural question is whether such cross-regional differences in per capita incomes are temporary or permanent. If they are temporary, unconditional convergence (to a common long-run level) may be occurring. This situation is usually captured by the unconditional $\beta$-convergence test. Now, if income differences are temporary but there remain doubts as to whether their dispersion is declining over time, then the $\sigma$-convergence test helps resolve this uncertainty. In contrast, if the differences are permanent, a crucial point to determine is whether this permanence reflects structural heterogeneity between regions or simply the role of initial conditions in determining long-run outcomes. In practice, the conditional $\beta$-convergence test requires a large set of controls to be employed in the estimation. ${ }^{4}$

4 If initial conditions determine long-run outcomes and countries with similar initial conditions exhibit similar long-run outcomes,
For the convergence hypothesis to be formalized empirically, the initial level of output is typically correlated with its growth rate. For relatively homogeneous groups of economic units at the regional level (such as states in the United States or Australia, provinces in Canada, prefectures in Japan and counties in Sweden), the unconditional $\beta$-convergence hypothesis has typically been applied. In this case, controls are not used in estimation. Even though there is some variation in estimated convergence rates at the international level, the range is relatively small: between $1 \%$ and $3 \%$ per year (Barro and Sala-i-Martin, 1992).

Figure 4 (left panel) and table 6 show the results of the unconditional $\beta$-convergence for economic growth in Colombian regions. The average growth rate of each region's per capita income for 1980-2012 is shown on the vertical axis and is negatively related to the log of per capita income in 1980, shown on the horizontal axis. Clearly, there is a phenomenon whereby poor regions tend to catch up with rich ones in terms of per capita income, with the gap being closed at a yearly rate of $0.86 \%$. When public accounts are subtracted from overall GDP to obtain a measure of private-sector GDP, the yearly rate falls to $0.66 \%$.

then it is possible to talk of convergence clubs (Durlauf, Johnson and Temple, 2005)

FIGURE 4

Convergence test for regional economic growth, 1980-2012
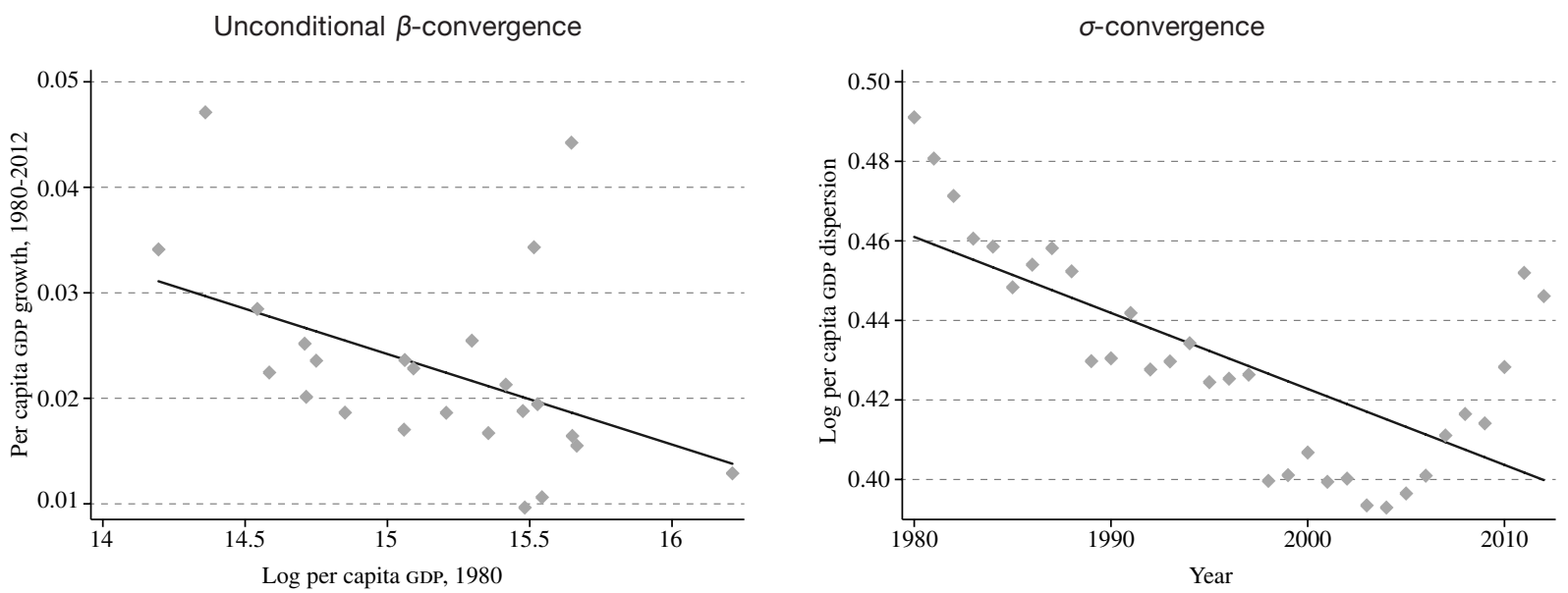

Source: Prepared by the authors.

Note: GDP: Gross domestic product. 
TABLE 6

\begin{tabular}{|c|c|c|c|c|}
\hline & \multicolumn{2}{|c|}{ Regional growth 1980-2012 } & \multicolumn{2}{|c|}{ Regional growth 1990-2012 } \\
\hline & Total GDP & Private-sector GDP & Total GDP & Private-sector GDP \\
\hline Constant & 0.15286 & 0.11871 & 0.2691 & 0.20688 \\
\hline$\beta$ & -0.00857 & -0.00656 & -0.01611 & -0.0124 \\
\hline$p$-value & 0.027 & 0.097 & 0.002 & 0.012 \\
\hline$R^{2}$ & 0.2029 & 0.1204 & 0.2812 & 0.1880 \\
\hline
\end{tabular}

Source: Prepared by the authors.

Note: GDP: Gross domestic product.

The unconditional $\beta$-convergence test was also performed for the period after the enactment of the Political Constitution of 1991, which promoted fiscal decentralization in Colombia. Table 6 clearly shows the per capita income gap between poorer and richer regions closing at a higher yearly rate of $1.61 \%$ in the more recent period $(1.24 \%$ when the private sector alone is considered). These simple exercises prompt recognition of the positive contribution of subnational governments to narrowing the differences in economic growth between regions in recent times. As stated at the beginning of the paper, the main argument for decentralization is that subnational governments have a better understanding of local needs. If local governments have made progress in satisfying unmet needs, then they are playing an important role in regional income convergence.

Lastly, we performed the $\sigma$-convergence test, according to which convergence entailed a decline in the standard deviation of the logarithm for per capita output across regions in Colombia from 1980 to 2012. Figure 4 (right panel) clearly shows the dynamic of this dispersion decreasing between 1980 and mid-2000. Curiously, though, it starts to increase again afterwards.

\section{VI}

\section{Concluding remarks}

This article has provided empirical evidence on the role of fiscal decentralization in Colombia's regional economic growth. The period analysed covers the last two decades, which is appropriate given that the Political Constitution of 1991 sought to encourage regional development. Also around this time, most Latin American countries reinforced the role of regional governments in their development strategies. Decentralization was placed at the heart of institutional reforms in the late twentieth century, especially in developing countries.

The empirical strategy involved the choice of an appropriate technique for the panel data approach which would make it possible to include a large set of factors suggested by the literature as determinants of economic growth, while successfully managing the main econometric problems. The augmented mean group (AMG) estimators proposed by Eberhardt and Bond (2009), Eberhardt and Teal (2010) and Bond and Eberhardt (2013) assisted in this. The strategy was supplemented with other empirical tools such as the cross-sectional models for different periods, together with other controls, the tests for unconditional convergence in regional income differences and, especially, the proofs of the hypothesis of complementarity between public goods provided by different jurisdictions.

Our results confirm the positive link between fiscal decentralization and economic growth across regions in Colombia, implying that the transfer of fiscal functions to subnational governments has been conducive to economic growth. These results are robust to the four most commonly used indicators of fiscal decentralization, two of them based on expenditure and tax autonomy and two on expenditure and revenue shares. The relationship found is also consistent with recent papers on this subject, even though no evidence was found for non-linearity. 
The positive effects of fiscal decentralization on regional growth were also confirmed through crosssectional models controlling for the initial level of output and human capital. The expected signs of the parameters for the remaining factors explaining growth were confirmed, and their elasticities were shown to be reasonable. The positive result for the common, unobservable factors helping to explain both economic growth directly and factor accumulation was also striking. Among them is total factor productivity, which could be affected in turn by region-differentiated aspects such as culture, habits, climate, geography, the quality of institutions, and so on. Lastly, the hypothesis was confirmed that public goods (especially infrastructure) supplied by different jurisdictions within Colombia have a significant indirect positive effect on growth in the other regions, although to a lesser extent than in the United States.

Lastly, we tried to assess whether per capita income differences between regions in Colombia had been declining, given the huge discrepancies observed three decades ago. Using unconditional $\beta$-convergence and $\sigma$-convergence tests, we found that the gap in per capita incomes between poorer and richer regions had been closing at a yearly rate of $1.61 \%$ for the most recent period, and that the dispersion of these income differences was declining over time. These results highlight the positive contribution of government activities.

\section{Bibliography}

Acemoglu, D., S. Johnson and J. Robinson (2005), "Institutions as a fundamental cause of long-run growth", Handbook of Economic Growth, Philippe Aghion and Steven N. Durlauf (eds.), vol. 1A, Amsterdam, Elsevier.

Akai, N., Y. Nishimura and M. Sakata (2007), "Complementarity, fiscal decentralization and economic growth", Economics of Governance, vol. 8, No. 4, Springer.

Asatryan, Z. (2010), "Fiscal decentralization and economic growth in OECD countries: a Bayesian model averaging approach", Berlin, unpublished.

Baltagi, B., G. Bresson and A. Pirotte (2008), "To pool or not to pool?", The Econometrics of Panel Data, L. Mátyás and P. Sevestre (eds.), Springer-Verlag.

Banerjee, A., M. Eberhardt and J.J. Reade (2010), "Panel estimation for worriers", Economics Series Working Papers, No. 514, University of Oxford.

Bardhan, P. and D. Mookherjee (2005), "Decentralization, corruption and government accountability: an overview", International Handbook on the Economics of Economic Corruption, S. RoseAckerman, Edward Elgar Publishing.

Barro, R. (1990), "Government spending in a simple model of endogenous growth", Journal of Political Economics, vol. 98, No. 5, Chicago, University of Chicago Press.

Barro, R. and X. Sala-i-Martin (1992), "Convergence", Journal of Political Economy, vol. 100, No. 2, Chicago, University of Chicago Press.

Baskaran, T., L. Feld and J. Schnellenbach (2009), "Fiscal federalism, decentralization and economic growth: survey and metaanalysis", CESifo Working Paper Series, No. 4985, Munich, CEsifo Group Munich.

Bénabou, R. (1996), "Heterogeneity, stratification, and growth: macroeconomic implications of community structure and school finance", American Economic Review, vol. 86, No. 3, Nashville, Tennessee, American Economic Association.

Blöchliger, H. (2013), "Decentralisation and economic growth. Part 1: how fiscal federalism affects long-term development", OECD Working Papers on Fiscal Federalism, No. 14, Paris, OECD Publishing.

Bond, S. and M. Eberhardt (2013), "Accounting for Unobserved Heterogeneity in Panel Time Series Models", University of Oxford, unpublished.

Bonet, J. (2006), "Desequilibrios regionales en la política de descentralización en Colombia", Documentos de Trabajo sobre Economía Regional, No. 77, Cartagena de Indias, Bank of the Republic.
Breinlich, H., G. Ottaviano and J. Temple (2013), "Regional growth and regional decline", CEPR Discussion Papers, No. DP9568, Centre for Economic and Policy Research.

Brueckner, J. (2001), "Fiscal decentralization in developing countries: the effects of local corruption and tax evasion", Annals of Economics and Finance, vol. 1, No. 18, University of Illinois.

Cass, D. (1965), "Optimum growth in an aggregative model of capital accumulation", The Review of Economic Studies, vol. 32, No. 3, Oxford University Press.

Coakley, J., A. Fuertes and R. Smith (2006), "Unobserved heterogeneity in panel time series models", Computational Statistics \& Data Analysis, vol. 50, No. 9, Amsterdam, Elsevier.

Davoodi, H. and H. Zou (1998), "Fiscal decentralization and economic growth: a cross-country study", Journal of Urban Economics, vol. 43, No. 2, Amsterdam, Elsevier.

Dell'Erba, S. and S. Sola (2013), "Does fiscal policy affect interest rates? Evidence from a factor augmented panel", Working Paper, No. 159, Washington, D.C., International Monetary Fund (IMF).

Durlauf, S., P. Johnson and J. Temple (2005), "Growth econometrics", Handbook of Economic Growth, Philippe Aghion and Steven N. Durlauf (eds.), vol. 1A, Amsterdam, Elsevier.

Eberhardt, M. and S. Bond (2009), "Cross-Section Dependence in Nonstationary Panel Models: a novel estimator", Munich Personal RePec Archive.

Eberhardt, M. and F. Teal (2010), "Productivity analysis in global manufacturing production", Economic Series Working Papers, No. 515, University of Oxford.

Faguet, J. and F. Sánchez (2009), "Decentralization and access to social services in Colombia", Documentos CEDE, No. 6, Bogota, University of the Andes.

(2008), "Decentralization effects on educational outcomes in Bolivia and Colombia", World Development, vol. 36, No. 7, Amsterdam, Elsevier.

Fisman, R. and R. Gatti (2002), "Decentralization and corruption: evidence across countries", Journal of Public Economics, vol. 83, No. 3, Amsterdam, Elsevier.

Hsiao, C. and M.H. Pesaran (2008), "Random coefficient models", The Econometrics of Panel Data, L. Mátyás and P. Sevestre (eds.), Springer-Verlag.

Kim, H. (2013), "Fiscal decentralization and economic growth in Korea", Korea Institute of Public Finance.

Koopmans, T. (1965), "On the concept of optimal economic growth", The Econometric Approach to Development Planning, Amsterdam, North-Holland. 
Iimi, A. (2005), "Decentralization and economic growth revisited: an empirical note", Journal of Urban Economics, vol. 57, No. 3, Amsterdam, Elsevier.

Im, K.S., M.H. Pesaran and Y. Shin (2003), "Testing for unit roots in heterogeneous panels", Journal of Econometrics, vol. 115, No. 1, Amsterdam, Elsevier.

Lee, K.S. and G. Roy (1999), Developing Towns and Cities: Lessons from Brazil and the Philippines, Washington, D.C., World Bank.

Levin, A., C. Lin and C.J. Chu (2002), "Unit root tests in panel data: asymptotic and finite sample properties", Journal of Econometrics, vol. 108, No. 1, Amsterdam, Elsevier.

Loboguerrero, A. (2008), "Decentralization in Colombia: why do localities respond to fiscal transfers in a different way?", Los Angeles, University of California.

Lozano, I. and M. Martínez (2013), "Enrollment and quality levels of Colombia's public basic education: has fiscal decentralization improved them?", Borradores de Economía, No. 747, Bogota, Bank of the Republic.

Manor, J. (1999), The Political Economy of Democratic Decentralization, Washington, D.C., World Bank.

Melo, L. (2005), "Impacto de la descentralización fiscal sobre la educación pública colombiana", Borradores de Economía, No. 350, Bogota, Bank of the Republic.

Moscone, F. and E. Tosetti (2009), "A review and comparison of tests of cross-section indpendence in panels", Journal of Economic Surveys, vol. 23, No. 3, Wiley.

Nishimura, Y. (2006), "Human fallibility, complementarity and fiscal decentralization", Journal of Public Economy Theory, vol. 8, No. 3, Wiley.

Oates, W. (1999), "An essay on fiscal federalism”, Journal of Economic Literature, vol. 37, No. 3, Nashville, Tennessee, American Economic Association.

Oxhorn, P., J. Tulchin and A. Selee (2004), Decentralization, Democratic Governance, and Civil Society in Comparative Perspective: Africa, Asia, and Latin America, Baltimore, Johns Hopkins University Press/Woodrow Wilson Center Press.
Pesaran, M.H. (2004), "General diagnostic tests for cross section dependence in panels", Cambridge Working Papers in Economics, No. 0435, University of Cambridge.

Ramírez, J., Y. Díaz and J. Bedoya (2014), "Decentralization in Colombia: searching for social equity in a bumpy economic", Working Paper, No. 62, FEDESARROLLO.

Ramsey, F. (1928), "A mathematical theory of saving", The Economic Journal, vol. 38, No. 152, Wiley.

Rodden, J. and S. Rose-Ackerman (1997), "Does federalism preserve markets?”, Faculty Scholarship Series, No. 590, Yale University.

Sánchez, F. (2006), "Descentralización y progreso en el acceso a los servicios sociales de educación, salud y agua y alcantarillado", Documentos CEDE, No. 15, Bogota, University of the Andes.

Sánchez, F. and M. Chacón (2005), "Conflicto, estado y descentralización: del progreso social a la disputa armada por el control local, 1974-2002", Documentos CEDE, Bogota, University of the Andes.

Stein, E. (1998), "Fiscal decentralization and government size in Latin America", Working Paper Series, No. 368, Washington, D.C., Inter-American Development Bank (IDB).

Tiebout, C. (1956), "A pure theory of local expenditures", Journal of Political Economy, vol. 64, No. 5, Chicago, University of Chicago Press.

Tulchin, J. and A. Selee (2004), "Decentralization and democratic governance in Latin America", Wilson Center Reports on the Americas, No. 12, Washington, D.C., Woodrow Wilson International Center for Scholars.

Villa E., J. Restrepo and M. Moscoso (2014), "Crecimiento económico, conflicto armado y crimen organizado, evidencia para Colombia", Costos económicos y sociales del conflicto en Colombia: ¿cómo construir un posconflicto sostenible?, Bogota, University of the Andes.

Weingast, B. (1995), "The economic role of political institutions: market-preserving federalism and economic development", The Journal of Law, Economics and Organization, No. 11, Oxford University Press.

ANNEXES

ANNEX A1

\section{Dataset description}

TABLE A1.1

\section{Panel data models}

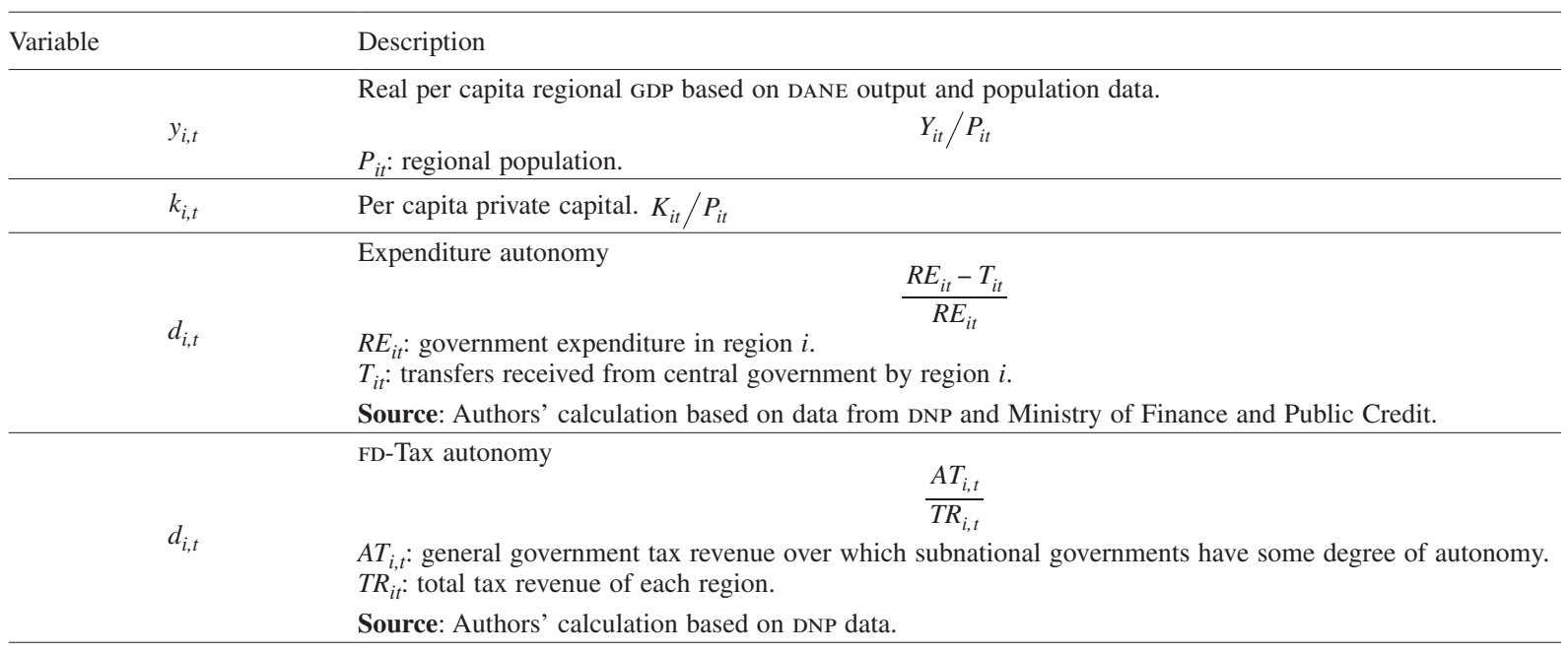


Table A1.1 (concluded)

\begin{tabular}{|c|c|}
\hline Variable & Description \\
\hline \multirow{3}{*}{$d_{i, t}$} & Expenditure share \\
\hline & $\begin{array}{l}R E_{i t}: \text { government expenditure in region } i \\
C E_{t}: \text { central government expenditure. }\end{array}$ \\
\hline & Source: Authors' calculation based on DNP data. \\
\hline \multirow{3}{*}{$d_{i, t}$} & FD-Revenue share \\
\hline & $\begin{array}{l}\text { T.REV }: \text { total revenue of region } i . \\
\text { C. } R E V: \text { total central government revenue. }\end{array}$ \\
\hline & Source: Authors' calculation based on DNP data. \\
\hline \multicolumn{2}{|l|}{ Other models } \\
\hline \multirow{3}{*}{$\ln N_{i, t}$} & Number of workers per capita \\
\hline & $\frac{\text { Economically active population }}{\text { Total nonulation }}$ \\
\hline & Source: DANE. \\
\hline \multirow{3}{*}{$\ln l_{i, t}$} & Logarithm of aggregate public goods in region $i$ \\
\hline & $\ln l_{i, t}=\frac{1}{\rho} \ln \left\{\frac{1}{J} \sum_{j=1}^{J} p_{t}(j)^{\rho}\right\}$ \\
\hline & $\rho$ : degree of global (inter-)complementarity between public services. \\
\hline \multirow{4}{*}{$p_{t}(j)$} & Implementation of public programmes financed by jurisdiction $j$ \\
\hline & $p_{t}(j)=m_{j}+d_{j}$ \\
\hline & $m_{j}:$ Expenditure of municipality $j$ \\
\hline & Source: Authors' calculation based on DNP data. \\
\hline \multirow{3}{*}{$d_{j}$} & Size of population ( \\
\hline & $d_{j}=\frac{\operatorname{pop}_{j}}{\text { pop }_{i}} l_{i}$ \\
\hline & Source: DANE. \\
\hline \multirow{4}{*}{$d_{i, t}$} & Average fiscal decentralization indicator \\
\hline & $\sum_{t=1}^{22} d_{i, t}$ \\
\hline & Soumen A thore, coloultion \\
\hline & Source: Authors' calculation. \\
\hline \multirow[t]{2}{*}{ Baseline variables } & $\begin{array}{l}\text { Baseline population level: } 1990 \text { population. } \\
\text { Baseline education level: } 1996 \text { education coverage. }\end{array}$ \\
\hline & Source: DANE. \\
\hline
\end{tabular}

Source: Prepared by the authors, on the basis of data from the National Administrative Department of Statistics (DANE), the National Planning Department (DNP) and the Ministry of Finance and Public Credit. 
ANNEX A2

Unit root and cross-sectional dependence tests for variables included in the panel data models

TABLE A2.1

Levin-Lin-Chu unit root test and Pesaran cross-sectional dependence (CD) test

\begin{tabular}{|c|c|c|c|c|c|}
\hline \multirow{2}{*}{ Variable } & \multicolumn{3}{|c|}{ Levin-Lin-Chu test ${ }^{\mathrm{a}}$} & \multicolumn{2}{|c|}{ Pesaran CD test $\mathrm{t}^{\mathrm{b}}$} \\
\hline & Coefficient & $p$-value & Lags & CD test & $p$-value \\
\hline$y_{\text {it }}$ & -1.07 & 0.00 & 1 & 21.80 & 0.00 \\
\hline$k_{i t}^{l t}$ & -1.21 & 0.00 & 1 & 37.31 & 0.00 \\
\hline Expenditure autonomy, $d_{i t}$ & -0.02 & 0.00 & 1 & 52.31 & 0.00 \\
\hline Tax autonomy, $d_{i t}$ & -0.34 & 0.00 & 1 & 38.49 & 0.00 \\
\hline Expenditure share, $d_{i t}$ & -0.27 & 0.02 & 3 & 47.92 & 0.00 \\
\hline Revenue share, $d_{i t}$ & -0.25 & 0.00 & 1 & 38.37 & 0.00 \\
\hline
\end{tabular}

Source: Prepared by the authors.

a Under the null hypothesis of non-stationarity.

b Under the null hypothesis of cross-sectional independence, $\mathrm{CD} \sim \mathrm{N}(0.1)$.

The different versions of the variables in equation (5) do not have unit roots, and display short-range autocorrelation and the presence of cross-sectional dependence. In fact, the $p$-values of the Levin-LinChu (2002) unit root tests (see the third column of table A2.1) are well below 0.05 , leading to the rejection of the unit root hypothesis, and thus of the existence of cointegration in equation (5). Furthermore, the number of optimal lags for these tests (see the fourth column of the same table) is small, at three or less, revealing short-term autocorrelation. Finally, Pesaran (2004) cross sectional independence hypothesis $p$-values (see the last column of the table) are well below 0.05 , indicating the presence of dependence among the regions for all versions of the variables in equation (5). These findings were also corroborated with other panel unit root tests (Im, Pesaran and Shin, 2003) with the same results. Therefore, the different versions of equation (1) correspond to stationary panels with variable-wise cross-sectional dependence among the 24 regions in Colombia.

To explore the existence of unobservable dynamic factors as sources of growth, a principal components analysis (PCA) was performed on all the regional GDP growth series. The results in the table below reveal that the first principal component explains $35 \%$ of the correlation between regions, while the second and third components explain $12 \%$ and $9 \%$, respectively. All these results suggest that dynamic factors might have to be brought in to explain the total variation of regional economic growth in Colombia, and this is in fact done by the AMG estimator used in this article.

TABLE A2.2

Principal components analysis of regional GDP growth

\begin{tabular}{|c|c|c|c|c|}
\hline Order & Eigenvalue & Difference & Proportion & Cumulative \\
\hline 1 & 8.35 & 5.51 & 0.35 & 0.35 \\
\hline 2 & 2.84 & 0.78 & 0.12 & 0.47 \\
\hline 3 & 2.06 & 0.09 & 0.09 & 0.55 \\
\hline 4 & 1.97 & 0.41 & 0.08 & 0.63 \\
\hline 5 & 1.56 & 0.17 & 0.07 & 0.70 \\
\hline 6 & 1.39 & 0.36 & 0.06 & 0.76 \\
\hline 7 & 1.03 & 0.14 & 0.04 & 0.80 \\
\hline 8 & 0.89 & 0.19 & 0.04 & 0.84 \\
\hline
\end{tabular}

Source: Prepared by the authors.

Note: GDP: Gross domestic product.

In all, the time series panels containing regional per capita output growth, private capital growth and the different fiscal decentralization indicators are stationary. Furthermore, there is clear evidence of cross-regional dependency, which may be related to spillovers and geographical correlation. Finally, there is evidence for unobserved factors driving output $\left(f_{t}\right)$, which may account for at least some variations in output growth. 